\title{
Atmospheric blocking induced by the strengthened Siberian High led to drying in west Asia during the 4.2 ka BP event - a hypothesis
}

\author{
Aurel Perşoiu ${ }^{1,2}$, Monica Ionita ${ }^{3}$, and Harvey Weiss ${ }^{4}$ \\ ${ }^{1}$ Emil Racoviţă Institute of Speleology, Romanian Academy, Cluj Napoca, 400006, Romania \\ ${ }^{2}$ Stable Isotope Laboratory, Ştefan cel Mare University, Suceava, 720229, Romania \\ ${ }^{3}$ Alfred Wegener Institute, Helmholtz Center for Polar and Marine Research, 27570 Bremerhaven, Germany \\ ${ }^{4}$ School of Forestry and Environmental Studies, Yale University, New Haven, CT, USA
}

Correspondence: Aurel Perşoiu (aurel.persoiu@gmail.com)

Received: 25 November 2018 - Discussion started: 6 December 2018

Revised: 27 March 2019 - Accepted: 29 March 2019 - Published: 11 April 2019

\begin{abstract}
Causal explanations for the $4.2 \mathrm{ka} \mathrm{BP}$ event are based on the amalgamation of seasonal and annual records of climate variability that was manifest across global regions dominated by different climatic regimes. However, instrumental and paleoclimate data indicate that seasonal climate variability is not always sequential in some regions. The present study investigates the spatial manifestation of the $4.2 \mathrm{kaBP}$ event during the boreal winter season in Eurasia, where climate variability is a function of the spatiotemporal dynamics of the westerly winds. We present a multi-proxy reconstruction of winter climate conditions in Europe, west Asia, and northern Africa between 4.3 and $3.8 \mathrm{ka}$. Our results show that, while winter temperatures were cold throughout the region, precipitation amounts had a heterogeneous distribution, with regionally significant low values in W Asia, SE Europe, and N Europe and local high values in the N Balkan Peninsula, the Carpathian Mountains, and E and NE Europe. Further, strong northerly winds were dominating in the Middle East and E and NE Europe. Analyzing the relationships between these climatic conditions, we hypothesize that in the extratropical Northern Hemisphere, the 4.2 ka BP event was caused by the strengthening and expansion of the Siberian High, which effectively blocked the moisture-carrying westerlies from reaching W Asia and enhanced outbreaks of cold and dry winds in that region. The behavior of the winter and summer monsoons suggests that when parts of Asia and Europe were experiencing winter droughts, SE Asia was experiencing similar summer droughts, resulting from failed and/or reduced monsoons. Thus, while in the extratropical regions
\end{abstract}

of Eurasia the $4.2 \mathrm{kaBP}$ event was a century-scale winter phenomenon, in the monsoon-dominated regions it may have been a feature of summer climate conditions.

\section{Introduction}

The 4.2 ka BP climate event was a ca. 200-300-year period of synchronous abrupt megadrought, cold temperatures, and windiness that were manifest globally (Walker et al., 2018). Coincident societal collapses and habitat tracking, particularly in regions where archaeological data are both extensive and high resolution, have attracted the attention of many paleoclimatologists and archaeologists since the event's first observation (Gasse and van Campo, 1994; Weiss et al., 1993; Dalfes et al., 1997). Numerous attempts have therefore been made to characterize and quantify the event's nature and to identify its causes at several levels of explanation. These studies have first defined the spatial extent and variability of the event. Megadrought developed abruptly at ca. $4.2 \mathrm{ka}$ cal BP across North America, Andean South America, the Mediterranean basin from Spain to Turkey (except for a few records from $\mathrm{N}$ Morocco and S Spain that indicate wetter conditions), Iran, India, Tibet, and north China and Australia (Booth et al., 2005; Staubwasser and Weiss, 2006; Arz et al., 2006; Berkelhammer et al., 2013; Cheng et al., 2015; Weiss, 2016; Kathayat et al., 2018). In southern Asia, failure of the monsoon (Wang et al., 2005) caused widespread droughts (Staubwasser et al., 2003; Berkelham- 
mer et al., 2013). Abrupt cold conditions, however, appeared at ca. $4.2 \mathrm{kacal} \mathrm{BP}$ in the northern North Atlantic (Geirsdóttir et al., 2019), the midlatitudes of the northern Eurasia (Hughes et al., 2000; Mayewski et al., 2004; Andresen and Björck, 2005; Mischke and Zhang, 2010; Larsen et al., 2012; Baker et al., 2017), and Antarctica (Peck et al., 2015) and surrounding oceans (Moros et al., 2009).

These descriptive data have encouraged numerous causal hypotheses at both a regional and, to a lesser extent, global level for the event's spatiotemporal distribution and qualities. Possible thermohaline circulation weakening or shutdown due to freshwater release in the North Atlantic (similar to the 8.2 ka event; Alley et al., 1997), changes in the loading of the Earth's atmosphere with aerosols or $\mathrm{CO}_{2}$ (Walker et al., 2012), and volcanic forcing (Kobashi et al., 2017) have been rejected as causes (Walker et al., 2012). At regional explanatory levels, cooling of the southern oceans (Moros et al., 2009) could have resulted in stronger and more frequent El Niño events that would have weakened (or led to the failure of) the southern Asian monsoons (Morrill et al., 2003; Walker et al., 2012).

The abrupt century-scale wet event recorded at very high resolution in North America at Mt. Logan, Yukon (Fisher et al., 2008), suggests an interval of massive advection of tropical air to NW North America linked to El Niño emergence at ca. $4.2 \mathrm{ka}$ (Shulmeister and Lees, 1995). A southward shift of the Intertropical Convergence Zone (ITCZ) could result in the observed cooling at high latitudes and stronger westerlies in the Northern Hemisphere and widespread drought in the tropics (Gasse and Van Campo, 1994; Mayewski et al., 2004). However, the widespread droughts both at the northern and southern margins of the ITCZ suggest that rather than migrating, the ITCZ was narrowing, resulting in megadrought affecting the tropics both south and north of the Equator (Weiss, 2016). Combining the above observations, it seems that while some of the climate variability at ca. $4.2 \mathrm{kacal} \mathrm{BP}$ can be attributed to regionally observable causes, explanations do not yet account for the global nature of the event, which includes the disruption of the westerlies and reduction of moisture advection to continents.

Hypothesized causal explanations for the $4.2 \mathrm{ka} \mathrm{BP}$ event are based on the amalgamation of winter, summer, and annual records of climate variability that was manifest in regions dominated by different climatic regimes (e.g., westerly dominated vs. monsoon dominated). However, both instrumental (Balling et al., 1998) and paleoclimate data (Perşoiu et al., 2017) indicate that, on scales ranging from annual to millennial, seasonal climate variability was not always sequential; i.e., warm (cold) summers were not always followed by warm (cold) winters. To address this conundrum, we have investigated the spatial manifestation of the $4.2 \mathrm{ka} \mathrm{BP}$ event during winter in a region dominated by climate variability induced by the strength and dynamics of westerly winds. We present a reconstruction of winter climate conditions in Europe, the Near East, and northern
Africa between 4.3 and $3.8 \mathrm{kacal} \mathrm{BP}$. From examination of the spatial distribution of temperature and precipitation excursions during this period, we hypothesize that, in the regions around the Eurasian landmass, the $4.2 \mathrm{ka} \mathrm{BP}$ event was caused by the strengthening and expansion of the Siberian high-pressure cell centered over western Asia that caused widespread cooling at midlatitudes in the Northern Hemisphere and aridification in the Middle East. We further discuss the possible causes and mechanisms leading to this phenomenon in a global perspective.

\section{Methods}

For our analysis, we have selected proxy records from Europe, the Middle East, northern Africa, and the Atlantic Ocean that cumulatively fulfilled a set of five criteria on interpretation, chronology, resolution, and nature of climatic variability. We have selected only records of winter climate variability, either precipitation amount (the vast majority) or air temperature, as indicated by the authors. Where no season was indicated we assumed that the proxy is recording annual climatic changes and we excluded it from our analysis. We have selected records with at least two absolute age determinations for the millennium encompassing the $4.2 \mathrm{ka} \mathrm{BP}$ event and for which measurement uncertainties were less than 50 years. A few high-resolution records from the fringes of the core study area (mainland continental Europe, the Middle East, and the Mediterranean basin) with age uncertainties up to 80 years were nevertheless used to refine the spatial interpretation of the results. To allow for chronological uncertainties, we have selected records that showed the onset of the local event within \pm 100 years of the accepted onset of the $4.2 \mathrm{ka}$ BP event (Walker et al., 2018) and a duration between 50 and 300 years. Further, we have considered only records that showed both an abrupt onset and termination (arbitrarily set to $15 \%$ against the preceding 100 years), matching the widely distributed $4.2 \mathrm{kaBP}$ event onset, and for which at least five data points exist for the 4300-3800 cal BP interval.

The response of European temperatures and precipitation to the variability of the Siberian High (SH) (Fig. 1) is based on the Climatic Research Unit Timeseries (CRU TS) 4.01 dataset (Harris et al., 2014). The relationship between the SH intensity, sea level pressure (SLP), and $10 \mathrm{~m}$ wind has been analyzed within composite maps for the years when the SH index was greater (high) and lower (low) than a value of 1 standard deviation. We have computed composite maps instead of correlation maps because the former considers the nonlinearities included in the analyzed data. The SH index has been obtained by averaging the SLP over the key regions between 40 and $65^{\circ} \mathrm{N}$ and between 80 and $120^{\circ} \mathrm{E}$ (Panagiotopoulos et al., 2005). The SLP and $10 \mathrm{~m}$ zonal and meridional wind data were extracted from the ERA 20C dataset (Poli et al., 2016). Our analysis has shown that the results are not sensitive to the exact threshold value used for our com- 


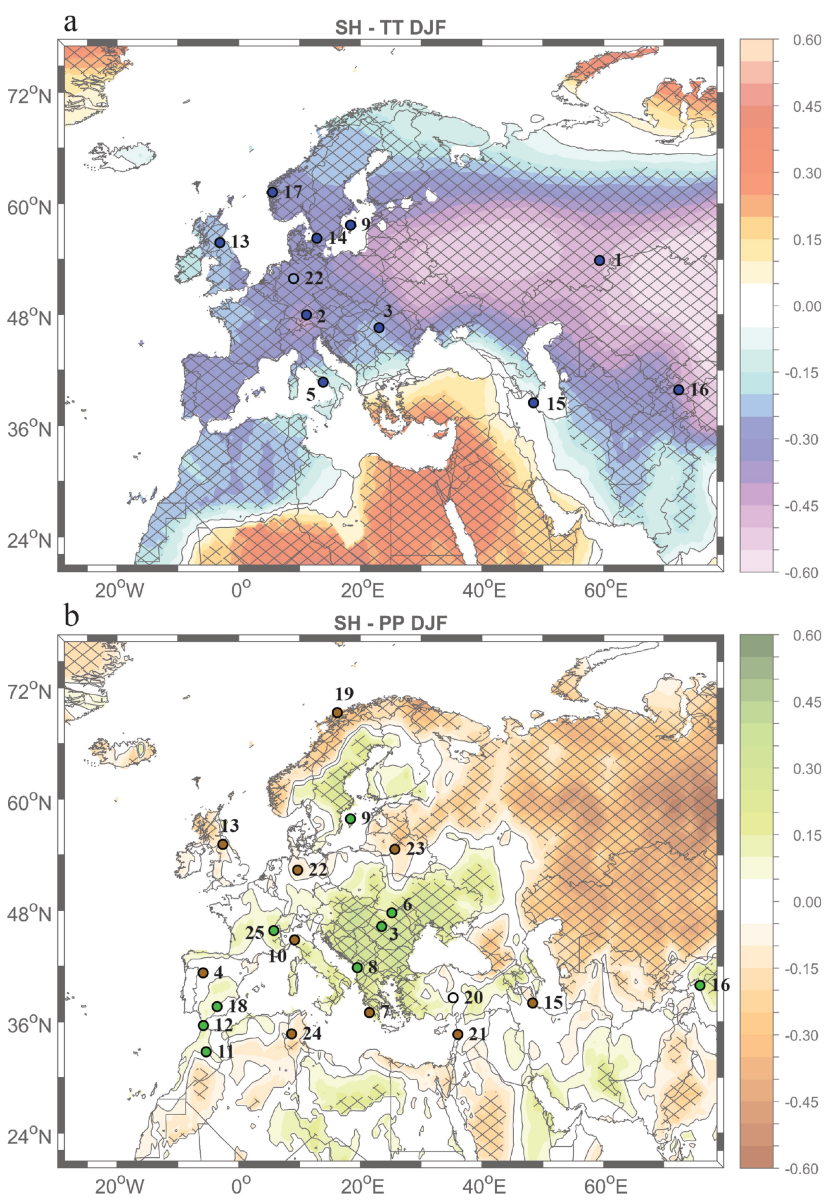

Figure 1. Climatic conditions at $4.2 \mathrm{ka} \mathrm{cal} \mathrm{BP}$ in Europe and western Asia. The background map in (a) shows the correlation between the winter $\mathrm{SH}$ index and the winter mean temperature (DecemberJanuary-February, DJF), with blue (red) shading indicating cold (warm) winters. The dots indicate winter climatic conditions at $4.2 \mathrm{ka}$ cal BP. The background map in (b) shows the correlation between the winter $\mathrm{SH}$ index and winter precipitation (DJF), with green (brown) indicating wet (dry) winters. Green (brown) dots in (b) indicate wet (dry) conditions at $4.2 \mathrm{ka} \mathrm{cal} \mathrm{BP}$. The hatched areas in (a) and (b) indicate correlations significant at the $95 \%$ level based on a Student's $t$ test. The numbers in (a) and (b) correspond to the archives listed in Table 1.

posite analysis (i.e., varying the standard deviation between 0.5 and 1.5). To isolate the interannual variations, the linear trend has been removed prior to the analysis from the $\mathrm{SH}$ index as well as from the analyzed fields.

\section{Results and discussion}

The list of records with information on the type of proxy used and its climatic interpretation, chronology, and resolution is presented in Table 1 and plotted in Fig. 1. Of the 30 selected proxies, 11 register winter (or cold season) temperature and 19 register winter precipitation amount. The temperature-sensitive proxies are from central and northern Europe and SW Asia, while the precipitation-sensitive proxies cover the entire study area (between $30^{\circ} \mathrm{W}$ and $80^{\circ} \mathrm{E}$ and between 20 and $78^{\circ} \mathrm{N}$ ), with a concentration in Europe, the Middle East, and northern Africa (Fig. 1). Both temperatureand precipitation-sensitive proxies were plotted against the map depicting the correlation between winter (DecemberJanuary-February, DJF) climate (temperature and precipitation) and a stronger than usual Siberian High (Fig. 1).

\subsection{Cold Europe and southwest Asia}

The $4.2 \mathrm{kaBP}$ event appears generally as cold during winter throughout Europe, from the Urals to the Atlantic Ocean (Fig. 1a). The highest amplitude of cooling is seen in the Ural Mountains (Baker et al., 2017) and at high altitude in the Alps (Fohlmeister et al., 2013), both recorded by speleothem $\delta^{18} \mathrm{O}$, as well as in central Asia (Wolff et al., 2017) recorded by speleothem $\delta^{13} \mathrm{C}$. Other records show only a moderate to weak cooling (Daley et al., 2010; Nesje et al., 2001; Muschitiello et al., 2013). The general picture that emerges from the data is that of westward decreasing cooling with increased distance from eastern Europe and western Asia. We did not find winter temperature proxies for SW Europe and the Middle East to fulfill our selection criteria; the majority of the proxies from this region are usually sensitive to precipitation amount changes.

Cold winters in Europe are associated with either blocking conditions over central Europe or westward expansion of the high-pressure cell - the Siberian High - centered over Asia (Cohen et al., 2001; Rîmbu et al., 2014; Ionita et al., 2018). In the Northern Hemisphere (NH), during the winter season, three semipermanent and quasi-stationary systems prevail over the middle to high latitudes: the Icelandic Low (over the Atlantic Ocean), the Aleutian Low (over the Pacific Ocean), and the Siberian High (SH). The SH is a semipermanent anticyclone centered over Eurasia and is associated with cold and dense air masses in the $\mathrm{NH}$ and extreme cold winters over Europe and Asia (Cohen et al., 2001). The composite maps of the SH index, SLP, and $10 \mathrm{~m}$ wind are shown in Fig. 2. As expected, in the case of a positive SH index (HIGH years, Fig. 2a) an extensive area of strong and positive SLP anomalies prevails over the whole Eurasian landmass, with the highest anomalies over Siberia. The positive anomalies in Fig. 2 were found to be statistically significant at the $5 \%$ level using a two-sample $t$ test. This SLP structure is associated with enhanced easterlies and advection of cold air towards Europe (blue background in Fig. 1a). For the years with a low index of the SH (Fig. 2b), negative SLP anomalies prevail over Siberia, while positive SLP anomalies are found over the central part of Europe. This kind of dipole-like structure in the SLP field associated with low SH years leads to the advection of warm air from the Atlantic Ocean basin towards the eastern part of Europe. 
Table 1. List of proxies used and their interpretation. Numbers in the first column correspond to numbers in Fig. 1.

\begin{tabular}{|c|c|c|c|c|c|c|}
\hline No. & Name & Proxy & Indicator of & Proxy interpretation & Years per sample & Reference \\
\hline 1 & Kinderlinskaya & Speleothem $\delta^{18} \mathrm{O}$ & $T_{\mathrm{W}}$ & Low values: cold & 12.5 & Baker et al. (2017) \\
\hline 2 & Spannagel Cave & Speleothem $\delta^{18} \mathrm{O}$ & $T_{\mathrm{W}}$ & $\begin{array}{l}\text { High values: cold, } \\
\text { NAO- }\end{array}$ & 5 & Fohlmeister et al. (2013) \\
\hline \multirow[t]{2}{*}{3} & \multirow[t]{2}{*}{ Scărişoara } & Ice $\delta^{18} \mathrm{O}$ & $T_{\mathrm{W}}$ & Low values: cold & \multirow[t]{2}{*}{10} & \multirow[t]{2}{*}{ Perşoiu et al. (2017) } \\
\hline & & d-excess & $M_{\text {source }}$ & $\begin{array}{l}\text { High values: } \\
\text { Mediterranean PP }\end{array}$ & & \\
\hline 4 & Asiul Cave & Speleothem $\delta^{18} \mathrm{O}$ & $\mathrm{PP}_{\mathrm{w}}$ & $\begin{array}{l}\text { Low values: } \\
\text { high precipitation }\end{array}$ & $1-28$ & Smith et al. (2016) \\
\hline \multirow[t]{2}{*}{5} & \multirow[t]{2}{*}{ Gulf of Gaeta } & G. $r u b e r \delta^{18} \mathrm{O}$ & $\mathrm{PP}_{\mathrm{w}}$ & $\begin{array}{l}\text { Low values: } \\
\text { high water inflow }\end{array}$ & \multirow[t]{2}{*}{55} & \multirow[t]{2}{*}{ Di Rita et al. (2018) } \\
\hline & & Globigerinoides \% & $T_{\mathrm{W}}$ & High values: cold & & \\
\hline 6 & Tăul Muced & Sphagnum $\delta^{13} \mathrm{C}$ & $\mathrm{PP}_{\mathrm{w}}$ & High values: wet & 8 & Panait et al. (2017) \\
\hline 7 & Mavri Trypa & Speleothem $\delta^{18} \mathrm{O}$ & $\mathrm{PP}_{\mathrm{w}}$ & High values: dry & 5 & Finné et al. (2017) \\
\hline 8 & Shkodra Lake & Carbonate $\delta^{18} \mathrm{O}$ & $\mathrm{PP}_{\mathrm{w}}$ & $\begin{array}{l}\text { High values: } \\
\text { low precipitation }\end{array}$ & $<50$ & Zanchetta et al. (2012) \\
\hline 9 & Lake Bjarstrask & Gastropod $\delta^{18} \mathrm{O}+\delta^{13} \mathrm{C}$ & $\mathrm{PP}_{\mathrm{w}}$ & $\begin{array}{l}\text { High values: } \\
\text { wet winters }\end{array}$ & 80 & Muschitiello et al. (2013) \\
\hline 10 & Buca della Renella & Speleothem $\delta^{18} \mathrm{O}$ & $\mathrm{PP}_{\mathrm{w}}$ & High values: dry & 37 & Drysdale et al. (2006) \\
\hline \multirow[t]{2}{*}{11} & \multirow[t]{2}{*}{ Sidi Ali Lake } & $\mathrm{CaCO}_{3}$ content & $\mathrm{PP}_{\mathrm{w}}$ & $\begin{array}{l}\text { Low values: } \\
\text { high lake level }\end{array}$ & 40 & \multirow[t]{2}{*}{ Zielhofer et al. (2017) } \\
\hline & & Ostracod $\delta^{18} \mathrm{O}$ & $\mathrm{PP}_{\mathrm{W}}$ & $\begin{array}{l}\text { Low values: } \\
\text { high \% of pp }\end{array}$ & 130 & \\
\hline 12 & Grotte de Piste & Speleothem $\delta^{18} \mathrm{O}$ & $\mathrm{PP}_{\mathrm{w}}$ & Low values: wet & 15 & Wassenburg et al. (2016) \\
\hline \multirow[t]{2}{*}{13} & \multirow[t]{2}{*}{ Walton Moss } & Sphagnum $\delta^{18} \mathrm{O}$ & $T_{\mathrm{W}}$ & Low values: cold & \multirow[t]{2}{*}{80} & \multirow[t]{2}{*}{ Daley et al. (2010) } \\
\hline & & Multi-proxy & $\mathrm{PP}_{\mathrm{w}}$ & Low values: dry & & \\
\hline 14 & Hyltemossen & Minerogenic content & Wind & $\begin{array}{l}\text { Low values: } \\
\text { weak winds }\end{array}$ & & Björck and Clemmensen (2004) \\
\hline 15 & Neor Lake & $\mathrm{Al}, \mathrm{Zr}, \mathrm{Ti}, \mathrm{Si}$ content & Dryness & High values: dry & 3.6 & Sharifi et al. (2015) \\
\hline 16 & Uluu Cave & Speleothem $\delta^{13} \mathrm{C}$ & $\mathrm{PP}_{\mathrm{w}}$ & $\begin{array}{l}\text { Low values: } \\
\text { wet-cold }\end{array}$ & 38 & Wolff et al. (2017) \\
\hline 17 & Jostedalsbreen & Grain size variations & $\mathrm{PP}_{\mathrm{w}}$ & $\begin{array}{l}\text { Low values: } \\
\text { dry winters }\end{array}$ & 21 & Nesje et al. (2001) \\
\hline 18 & Refugio & Stalagmite density & $\mathrm{PP}_{\mathrm{w}}$ & $\begin{array}{l}\text { Low values: } \\
\text { dry winters }\end{array}$ & 5 & Walczak et al. (2015) \\
\hline 19 & Nattmasvatn & Minerogenic input & $\mathrm{PP}_{\mathrm{w}}$ & Low values: dry & - & Janbu et al. (2011) \\
\hline 20 & Nar Gölü Lake & Diatom $\delta^{18} \mathrm{O}$ & $\mathrm{PP}_{\mathrm{w}}$ & $\begin{array}{l}\text { Low values: } \\
\text { more winter rainfall }\end{array}$ & 5 & Dean et al. (2018) \\
\hline 21 & Jeita Cave & Speleothem $\delta^{18} \mathrm{O}$ & $\mathrm{PP}_{\mathrm{w}}$ & High values: dry & 7 & Cheng et al. (2015) \\
\hline 22 & Bunker Cave & Speleothem $\mathrm{Mg} / \mathrm{Ca}$ & $\mathrm{PP}_{\mathrm{w}}$ & High values: dry & - & Wassenburg et al. (2016) \\
\hline 23 & Nuudsaku Lake & Carbonate $\delta^{18} \mathrm{O}$ & $\mathrm{PP}_{\mathrm{w}}$ & $\begin{array}{l}\text { High values: } \\
\text { dry winters }\end{array}$ & 13 & Stansell et al. (2017) \\
\hline 24 & Gueldaman Cave & Speleothem $\delta^{18} \mathrm{O}$ & $\mathrm{PP}_{\mathrm{w}}$ & High values: dry & - & Ruan et al. (2016) \\
\hline 25 & Lake Petit & Detrital input & $\mathrm{PP}_{\mathrm{w}}$ & High values: wet & - & Cartier et al. (2019) \\
\hline
\end{tabular}



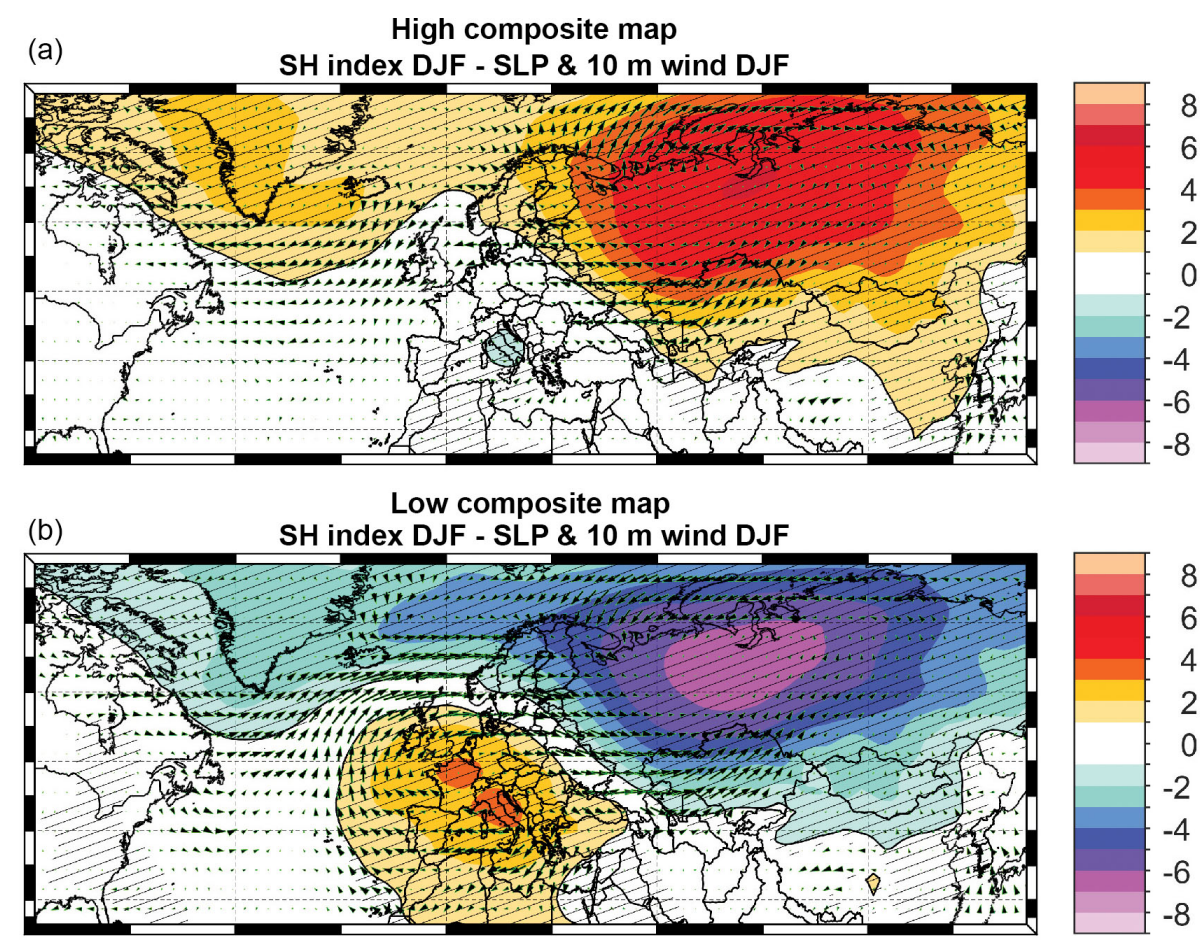

Figure 2. The composite map of the winter (DJF) sea level pressure (SLP) and wind at $10 \mathrm{~m}$ for the years when the SH index $>1$ standard deviation (a) and the composite map of the winter (DJF) sea level pressure (SLP) and wind at $10 \mathrm{~m}$ for the years when the SH index $<-1$ standard deviation (b). The hatching highlights significant SLP anomalies at a confidence level of $95 \%$ based on a Student's $t$ test. The SLP units are in hectopascals (hPa).

The robust association between the instrumental-based response of European and Asian temperatures to a strong SH (base map in Fig. 1) and the proxy-based reconstructions of winter air temperatures (blue dots in Fig. 1a) supports the hypothesis that a strengthened $\mathrm{SH}$ was active at the time of the $4.2 \mathrm{kaBP}$ event (the possible mechanisms are described below). The seasonality of the SH implies its onset in midautumn, likely linked to diabatic heating anomalies initiated by snow cover development in NE Siberia (Foster et al., 1983; Cohen et al., 2001). The cooling resulting from the expanding snow cover leads to anomalously high SLP in NE Asia, which in turn results in more snowfall and further strengthening of the SLP anomaly. The rapidly developing high-pressure and cold anomaly extends westwards, being limited towards the north and east by the warm ocean SSTs (Cohen et al., 2001). The end result of an enhanced SH is a westward-rolling high-pressure system that also brings cold air, heavy snowfall, and strong winds towards both Europe and central Asia (Ding and Krishnamurti, 1987; Gong and Ho, 2002; Panagiotopoulos et al., 2005). The development of the SH also leads to strengthening of the subtropical jet stream over SE China (Panagiotopoulous et al., 2005), a characteristic feature of the East Asian winter monsoon (EAWM; Cheang, 1987), and instrumental data (Wu and Wang, 2002; Jhun and Lee, 2004) show that strengthening of the SH results in a stronger than average EAWM. Paleocli- mate data from Asia further indicate the strengthening of the EAWM at $4.2 \mathrm{ka} \mathrm{cal} \mathrm{BP} \mathrm{(e.g.,} \mathrm{Hao} \mathrm{et} \mathrm{al.,} \mathrm{2017;} \mathrm{Giosan} \mathrm{et} \mathrm{al.,}$ 2018), likely linked to stronger and more frequent outbreaks of cold air from the core of the SH. Similarly, paleoclimate records from the outer limits of the region impacted by the SH have documented significant increases in the strength of the local winds, frequently a local diagnostic signature of the $4.2 \mathrm{ka} \mathrm{BP}$ event. Various proxies in different sedimentary archives across west Asia have documented strong northerly winds at $4.2 \mathrm{ka}$ cal BP: soil micromorphology at Tell Leilan (NE Syria; Weiss et al., 1993), detrital dolomite and calcite in Gulf of Oman (Cullen et al., 2000) and Red Sea (Arz et al., 2006) marine cores, high Ti counts in Lake Neor on the Iranian plateau (Sharifi et al., 2015), S/Ti ratios in Lake Kinneret, Israel (Vossel et al., 2018), and lake bed sediments in the UAE (Parker et al., 2006).

The strengthened EAWM and high windiness in SW Asia are consistent with the climatology of the $\mathrm{SH}$, with a strong clockwise flow of anomalously cold air from its center of action, located in north-central Asia (Fig. 2a). Paleoclimate records from Europe also document $4.2 \mathrm{kaBP}$-related increases in wind strength and/or storminess, such as at the raised bogs in SW Sweden (linked to cold temperatures and possible increased sea ice; Björck and Clemmensen, 2004), aeolian sandbanks in coastal Denmark (Clemmensen et al., 2003; Goslin et al., 2018), and Gotland, Baltic Sea (Muschi- 


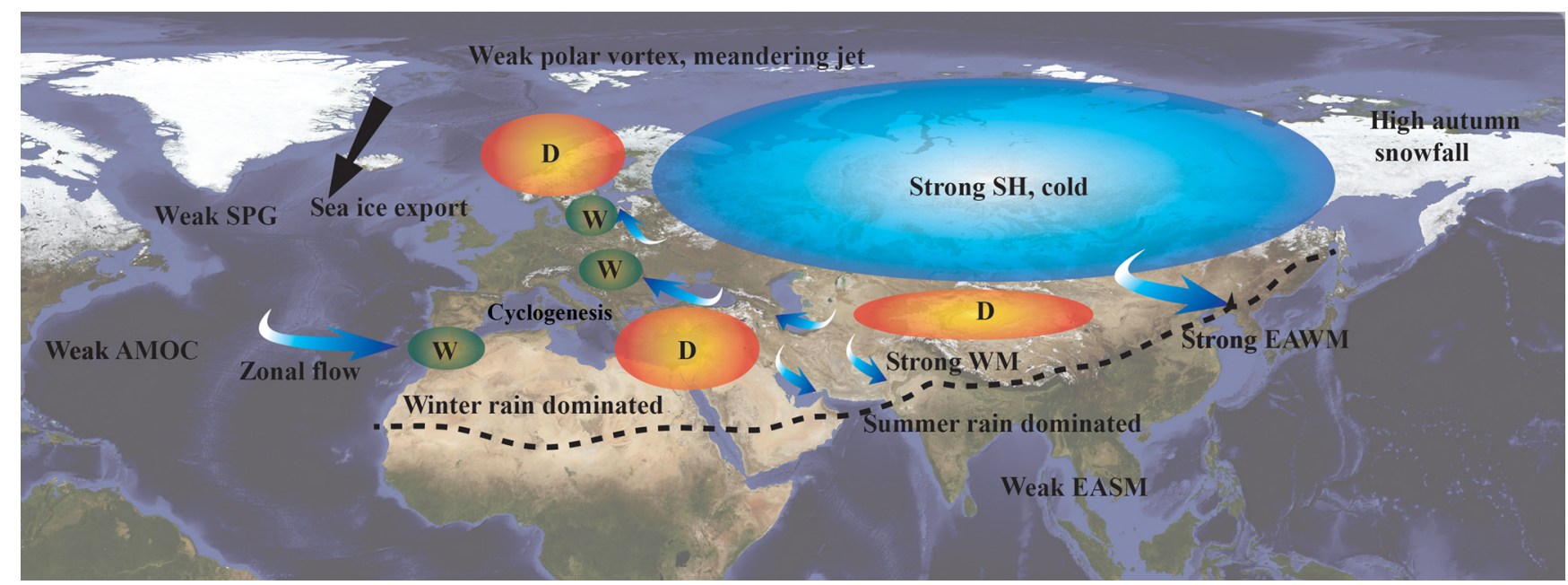

Figure 3. Inferred winter climatic conditions between $\sim 4.3 \mathrm{ka}$ and $3.9 \mathrm{kacal} \mathrm{BP}$. The position of the polar vortex is only indicative. The base map shows the Earth's surface conditions during November (Reto Stöckli, NASA Earth Observatory).

tiello et al., 2013) (Fig. 3), where strong winter winds and high precipitation, the product of Baltic Sea moisture delivered by intense easterly winds, indicate the reinforcement and westwards expansion of the Siberian High. These data suggest that a belt of strong winds extended around the core region of the $\mathrm{SH}$, from East Asia through west Asia and $\mathrm{SE}$ Europe up to the Baltic and North Sea (Fig. 3).

Summarizing the above information, at ca. $4.2 \mathrm{ka}$ a cold temperature anomaly settled over most of Europe from the Ural Mountains to the Atlantic Ocean, including Scandinavia, and extending to the region south and east of the Caspian Sea, likely the result of a deeper than average Siberian High. Further, anomalously high SLP over this region resulted in the strengthening of winter winds in eastern, southern, and southwestern Asia and eastern and northeastern Europe, linked to the clockwise and outward movement of cold air from the core of the SH-impacted region.

\subsection{Inconsistent winter precipitation patterns across Europe and southwest Asia}

Data from winter precipitation records at the time of the $4.2 \mathrm{ka}$ BP event suggest a far more complex image of precipitation distribution across our study area (Fig. 1b) compared with the simpler temperature distribution dipole (Fig. 1a). The SE Mediterranean and the wider Middle East were dry (Bini et al., 2018), with most of the droughts occurring rather abruptly (Cheng et al., 2015; Sharifi et al., 2015; Dean et al., 2018). In the wider Mediterranean basin, winter drought was also recorded in S Greece (Finné et al., 2017), northcentral Italy (Drysdale et al., 2006; Regattieri et al., 2014; Isola et al., 2019), N Algeria (Ruan et al., 2016), and central Spain (Smith et al., 2016), with all records pointing towards an abrupt onset and a ca. 150-200-year duration. Against this background of generalized megadrought in the
Mediterranean, in two regions an increase in winter precipitation amounts was registered (Fig. 1b), most notably in NW Africa and SW Europe (Walczak et al., 2015; Wassenburg et al., 2016; Zielhofer et al., 2017) as well as in the central Balkans and Carpathian Mountains (Zanchetta et al., 2012; Panait et al., 2017; Perşoiu et al., 2017). Multiple records and different proxies (speleothem and lake sediment $\delta^{18} \mathrm{O}$, peat bog $\delta^{13} \mathrm{C}$, cave ice d-excess and growth rate) indicate similarly wet conditions, clearly underscoring the wet nature of the climate at that time in these two regions. The high winter precipitation amounts registered by records in the Balkan Peninsula and the Carpathian Mountains (Fig. 1b) occurred during periods of intense cold (Fig. 1a). Winter precipitation in the Carpathian Mountains is the result of either eastward advection of wet air masses of Atlantic origin or precipitation from northward-traveling Mediterranean cyclones encountering the NE winds induced by a strong SH. The $\delta^{18} \mathrm{O}$ and d-excess records from Scărişoara Ice Cave (Perşoiu et al., 2017) indicate that at $4.3 \mathrm{kacal} \mathrm{BP}$, late autumn through early winters were cold and the moisture source was shifted to an area of high evaporation (as indicated by the high dexcess values). Modern monitoring of stable isotopes in precipitation in the region (Drăguşin et al., 2017; Ersek et al., 2018; Bădăluţă et al., 2019) indicates that high d-excess values occur when the source of moisture is either the eastern Mediterranean Sea or the Black Sea. A Black Sea source for the moisture leading to high precipitation in the Carpathian Mountains is consistent with the information of prevailing northeasterly winds at $4.2 \mathrm{ka}$ (see Sect. 3.1. above), but it would not fully explain the possibly wet conditions on the Adriatic coast at $4.3 \mathrm{kacal}$ BP (Fig. 1b, Zanchetta et al., 2012), where high winter precipitation is the result of moisture originating in the Adriatic Sea (Ulbrich et al., 2012). We note, however, that the Adriatic coast could also have been dry at $4.2 \mathrm{ka}$, as suggested by a spike in the carbonate $\delta^{18} \mathrm{O}$ 
record of Shkodra Lake (Zanchetta et al., 2012). Interestingly, the response of present-day climatic conditions in Europe to a stronger than usual Siberian High is low SLP in the central Mediterranean Sea (centered on Italy, Fig. 2a), which in turns results in enhanced cyclogenesis in the area. Thus, in the case of strong SH conditions at $4.2 \mathrm{ka}$, enhanced cyclogenesis would have resulted in more frequent NW movement of moisture-bearing weather systems, further leading to higher than average precipitation on the Adriatic coast and the Carpathian Mountains (Fig. 1b). Apart from the high dexcess in the Scărişoara Ice Cave record (Perşoiu et al., 2017) at $4.3 \mathrm{ka}$, indicative of Mediterranean moisture, the ice accumulation rate also reached a maximum at that time, suggesting high precipitation amounts and the early onset of freezing conditions in the cave, both favorable for the rapid growth of ice (Perşoiu et al., 2011).

Apart from SW Europe, the Balkans, and the Carpathian Mountains, high precipitation at $4.2 \mathrm{ka}$ in Europe was also registered in a lake at the foothills of the Alps (Cartier et al., 2019) and in Gotland, the Baltic Sea (Muschitiello et al., 2013). In the Alps, high flooding activity at $4.2 \mathrm{ka}$ was linked to increased autumn precipitation (Cartier et al., 2019), while in the Baltic, high winter precipitation is consistent with strong easterly winds picking up local moisture form the Baltic Sea (Muschitiello et al., 2013, as well as the discussion in Sect. 3.1 above).

The winter precipitation record in Europe and the Middle East can now be summarized as follows (Fig. 1b).

1. Regionally significant dry conditions occurred during winter in the Middle East, southern Europe (Italy and Greece), northern Africa, and on a band stretching from the Atlantic Ocean, through the north European plains, towards eastern Europe, including Scandinavia.

2. Regionally significant wet conditions occurred during winter around the Strait of Gibraltar (northern Morocco and southern Spain) and in the northern Balkan Peninsula (including the Carpathian Mountains).

The distribution of precipitation minima and maxima on the western (Atlantic) side of Europe is similar to that occurring during the negative phase of the North Atlantic Oscillation (NAO), one of the main modes of climate variability in Europe (Hurrell et al., 2013) that is mainly active during winter. The NAO is defined as the difference in atmospheric pressure between the Icelandic Low and the Azores High. A below average difference between the two pressure systems (negative NAO, or NAO-) results in weaker than usual and southward-deflected westerly winds, carrying more moisture towards southern Europe. As precipitation amounts are negatively correlated with the NAO phase in the western Mediterranean (i.e., NAO - results in high precipitation; Lionello et al., 2006), the reconstructed distribution of precipitation at $4.2 \mathrm{ka}$ (Fig. 1b) partly supports the hypothesis of prevailing NAO- conditions during the $4.2 \mathrm{kaBP}$ event. Proxy-based reconstructions of the NAO index (Olsen et al., 2012) indicate a brief negative mode at $4.2 \mathrm{ka}$ cal BP, but contradictory evidence from speleothem and pollen data from the central Mediterranean region (e.g., Bini et al., 2019, and references therein) suggests that a combination of different mechanisms (including NAO- conditions) could have been responsible for the winter climatic conditions at $4.2 \mathrm{ka}$ in Europe.

\subsection{The Siberian High in the global context at $4.2 \mathrm{ka}$}

The paleoclimate evidence we have compiled collectively suggests cold winter conditions in N Asia and Europe, likely induced by cold air outbreaks from high-pressure fields located over Siberia, conditions that in modern climates are associated with a strong Siberian High. The sole reconstruction of the past behavior of the Siberian High is based on an analysis of the continental-sourced nss $\mathrm{K}^{+}$(non-sea-salt potassium) in Greenland ice cores (Mayewski et al., 1994; O'Brien et al., 1995). Meeker and Mayewski (2002) have shown that in years with high nss $\mathrm{K}^{+}$deposits in Greenland, the SLP over N Asia in spring (indicator of the strength of the $\mathrm{SH}$ ) is higher than average, thus providing a possible proxy for the strength of the Siberian High. The reconstructed values for the strength of the SH (using the original data of Mayewski et al., 1997) on the GICC05modelext timescale (Seierstad et al., 2014) show a maximum at around $4.3 \mathrm{ka}$, in agreement within dating uncertainties with the paleoclimate data presented in Fig. 1.

Previous studies based on instrumental, tree ring, and ice core impurity content have shown a clear link between a strong SH and a cold and dry climate in Europe (Meeker and Mayewski, 2002; D'Arrigo et al., 2005). The close match between the impact of the $\mathrm{SH}$ on temperature and precipitation amounts and the reconstructed climate (Fig. 1) suggests that at $4.2 \mathrm{ka}$ there was a stronger than usual $\mathrm{SH}$, leading to cooling in Asia and Europe, disruption of the westerlies, and drought in the Middle East (Fig. 3). The possible causes of this chain of events remains, however, elusive. Some possible forcings behind climate changes do not appear abruptly at $4.2 \mathrm{ka}$. Orbital forcing resulted in low winter insolation in the Northern Hemisphere and comparably high, but decreasing, summer insulation, while radiative forcing was going through a remarkably long state of stable, albeit high, values (Steinhilber et al., 2009). Volcanic and greenhouse forcing were both low and stable at $4.2 \mathrm{ka}$, with no abrupt changes (e.g., Wanner et al., 2011). The high contrast between summer and winter insolation would have resulted in a weak polar vortex (Orme et al., 2017) and thus more meridional polar vortex and associated southward-displaced storm tracks in the Atlantic. The same meridionally displaced polar vortex could have led to cold air advection to $\mathrm{N}$ Asia and the early onset of winter, with earlier formation of snow cover.

The early presence and persistence of snow in NE Asia is one of the most important triggers of a strong SH (Cohen et al., 2001; Wu and Wang, 2002). The causes and mech- 
anisms by which snow accumulates in early winter in NE Asia are elusive; possible causes include a positive feedback from the NAO, with NAO- conditions in late winter-early spring leading to an early beginning of snow accumulation in the following winter and subsequent onset of a strong $\mathrm{SH}$ (Bojariu and Gimeno, 2003). The NAO index (Olsen et al., 2012) shows a continuous change from $\mathrm{NAO}+$ to NAOconditions after $4.5 \mathrm{ka}$, with a distinct negative excursion at $4.2 \mathrm{ka}$. A weak NAO would have resulted in low wind stress and associated enhancement of the salinity stratification in the North Atlantic, initiating the slowdown of the Atlantic Meridional Overturning Circulation (AMOC; Yang et al., 2016). Thornalley et al. (2009) have documented a rapid and abrupt reduction in salinity at $4.2 \mathrm{ka}$ that could have triggered the weakening of the AMOC. Reduced strength of the AMOC could have further led to the southward expansion of sea ice and thus a further decrease in salinity and weakening of the AMOC (Yang et al., 2016). Further, negative NAO conditions are also linked to a weakening of the subpolar gyre (Eden and Jung, 2001; Häkkinen and Rhines, 2004) and thereby a reduced contribution of freshwater to the AMOC and further cooling in the Nordic Seas. Similarly, weak NAO conditions result in stronger northeastern winds and increase in the strength of the East Greenland current and associated sea ice export, further leading to the weakening of the thermohaline circulation (Orme et al., 2018) and subsequent cooling of the North Atlantic, as seen in both paleodata and models (e.g., Rîmbu et al., 2003; Renssen et al., 2005; Berner et al., 2008; Sejrup et al., 2016; Orme et al., 2018). In turn, these conditions led to reduced SLP around Iceland and a reinforcement of the negative NAO.

The above inferences suggest that at ca. $4.2 \mathrm{ka}$, orbital and solar forcing led to a chain of atmospheric changes, transmitted and amplified by ocean circulation, which caused abrupt cold and dry climatic conditions in northern Eurasia. These atmospheric changes included the weakening of the polar vortex and southward advection of cold air over $\mathrm{N}$ Asia. The enhanced meridional transport generated earlier and more persistent autumn snow cover. In turn, this led to the onset of a stronger than usual Siberian High that lowered Eurasian surface temperatures with strong outbreaks of cold and dry northerly winds in a belt stretching from eastern Asia through portions of west Asia and central and northern Europe. The above average SLP associated with the strengthened SH resulted in the blocking of the moisture-bearing westerlies in Europe. Megadrought across the Mediterranean and west Asia may have also been enhanced by the weak and southward-displaced Atlantic storm track that resulted from lower than average NAO conditions. The conditions associated with a weak polar vortex strengthened sea ice towards the Nordic Seas, further contributing to the weakening of the thermohaline circulation and reduction in the strength of the $\mathrm{NAO}$ and the westerlies.

\section{Conclusions}

We have gathered records of changes in winter temperature, precipitation amount, and associated climatic conditions in the wider Eurasian region during the $4.2 \mathrm{ka} \mathrm{BP}$ event. The data show that 4200 years ago cold winter temperature anomalies dominated western Asia and most of Europe. The strength of winter winds in eastern and southern Asia was strongly enhanced, while those in western Europe weakened. Regionally significant droughts settled over the Middle East, southern and northern Europe, and western Asia, while locally significant increases in precipitation were reconstructed in the Balkan Peninsula, the Carpathian Mountains, around the Baltic Sea, and in NW Africa and southern Spain.

We propose a multi-causal hypothesis of partially mutual reinforcing vectors and mechanisms to explain the regionally coherent north Eurasian and adjacent region $4.2 \mathrm{ka}$ phenomena. Thus, we hypothesize that before and at $4.2 \mathrm{ka}$, the orbitally induced high insolation gradient between summer and winter in the high latitudes of the Northern Hemisphere led to a weakening of the polar vortex, resulting in a meandering jet that promoted an early onset of winter in NE Siberia. In turn, this resulted in decreasing temperatures and an early and stronger Siberian High that expanded south and westwards, bringing cold and dry conditions across Eurasia. The same circulation pattern led to more sea ice export in the North Atlantic and weakening of the subpolar gyre, resulting in the slowdown of the thermohaline circulation and a decrease in sea level pressure around Iceland, thus possibly leading to a shift towards a negative phase of the North Atlantic Oscillation. In turn, these changes resulted in weaker and southward-displaced westerly winds across Europe. However, the high-pressure systems in Europe effectively blocked these weakened westerlies, causing reduced winter precipitation and drought conditions across the eastern Mediterranean and western Asia. Clockwise circulation around the Asia-centered high-pressure field induced strong northerly winds in southern and western Asia and in eastern Europe. Further, the strong thermal pressure gradient between central and northern Asia and the Indian and $\mathrm{Pa}-$ cific oceans determined the strengthening of the East Asian and Indian winter monsoons. However, given the drought in the source regions of the winter monsoon, these strengthened winds did not result in increased moisture advection. Nevertheless, several regions experienced a slight increase in winter precipitation due to strong winds picking up moisture from local sources (NW Africa, N Balkan Peninsula and the Carpathian Mountains, the Baltic region).

In the context of the above data and description, we suggest that, in the extratropical regions of Eurasia, the $4.2 \mathrm{kaBP}$ event was an abrupt century-scale boreal winter phenomenon. While not the subject of our study, we note that a clear antiphase behavior of the winter and summer monsoons has been evidenced (Kang et al., 2018), suggesting that at the times when parts of Asia and Europe were 
experiencing winter droughts related to strong, dry, winter monsoons, SE Asia was experiencing similar abrupt summer megadroughts resulting from failed and/or reduced monsoons. Whether these were caused by the same orbitally induced changes and/or teleconnections transmitted via the weakened AMOC are questions to be investigated within future proxy-based and modeling studies. Especially important would be winter precipitation records from western Asia and eastern Europe, as well winter temperature records from southern Europe and the wider Middle East, where such data are scarce. Further, most of the winter records are of low resolution and/or with poor chronological control such that improvements in these fields are required to further test our hypothesis.

Data availability. All data in this study have been obtained from the cited references.

Author contributions. AP designed the hypothesis, AP and HW collected, reviewed, and analyzed the paleoclimate data, AP and MI discussed the climatology of the SH, and AP synthesized the evidence and wrote the text with input from HW and MI. MI drew the base maps in Fig. 1 and created Fig. 2.

Competing interests. The authors declare that they have no conflict of interest.

Special issue statement. This article is part of the special issue "The 4.2 ka BP climatic event". It is a result of "The $4.2 \mathrm{ka} \mathrm{BP}$ Event: An International Workshop", Pisa, Italy, 10-12 January 2018.

Acknowledgements. The Scărişoara ice core analyses in Romania were partially supported by UEFISCDI Romania through grant nos. PN-III-P1-1.1-TE-2016-2210 and PNII-RU-TE-2014-4-1993 awarded to Aurel Perşoiu, ELAC2014/DCC-0178/FP7, and contract 18PFE/16.10.2018 funded by the Ministry of Research and Innovation in Romania within Program 1 - Development of national research and development system, Subprogram 1.2 - Institutional Performance-RDI excellence funding projects. Aurel Perşoiu further acknowledges support from SP-PANA-W1010. The Associazione Italiana per lo studio del Quaternario and the organizers of the "4.2 ka BP Event: An International Workshop" (Pisa, Italy) financially supported Aurel Perşoiu for attendance at the workshop where some of the ideas presented here were born. Monica Ionita was funded by the Helmholtz Climate Initiative REKLIM and by the Polar Regions and Coasts in the Changing Earth System (PACES) program of the AWI. We thank the editor, Giovanni Zanchetta, and two anonymous referees for their comments.
Review statement. This paper was edited by Giovanni Zanchetta and reviewed by two anonymous referees.

\section{References}

Alley, R. B., Mayewski, P. A., Sowers, T., Stuiver, M., Taylor, K. C., and Clark, P. U.: Holocene climatic instability: A prominent, widespread event 8200 yr ago, Geology, 25, 483-486, 1997.

Andresen, C. and Björck, S.: Holocene climate variability in the Denmark Strait region - a land-sea correlation of new and existing climate proxy records, Geogr. Ann. A, 87, 159-174, 2005.

Arz, H. W., Lamy, F., and Pätzold, J.: A pronounced dry event recorded around $4.2 \mathrm{ka}$ in brine sediments from the Northern Red Sea, Quaternary Res., 66, 432-441, 2006.

Baker, J. L., Lachniet, M. S., Chervyatsova, O., Asmerom, Y., and Polyak, V. J.: Holocene warming in western continental Eurasia driven by glacial retreat and greenhouse forcing, Nat. Geosci., 10, 430-435, 2017.

Balling, R., Michaels, P. J., and Knappenberger, P. C.: Analysis of winter and summer warming rates in gridded temperature time series, Clim. Res., 9, 175-181, 1998.

Bădăluţă, C.-A., Perşoiu, A., Ioniţă, M., Nagavciuc, V., and Bistricean, P.-I.: Stable $\mathrm{H}$ and $\mathrm{O}$ isotope-based investigation of moisture sources and their role in river and groundwater recharge in the NE Carpathian Mountains, EastCentral Europe, Isot. Environ. Healt. S., 55, 161-178, https://doi.org/10.1080/10256016.2019.1588895, 2019.

Berkelhammer, M., Sinha, A., Stott, L., Cheng, H., Pausata, F. S. R., and Yoshimura, K.: An abrupt shift in the Indian Monsoon 4000 years ago, in: Climates, Landscapes, and Civilizations, edited by: Giosan, L., Fuller, D. Q., Nicoll, K., Flad, R. K., and Clift, P. D., American Geophysical Union, Washington, DC, 75-87, 2013.

Berner, K. S., Koç, N., Divine, D., Godtliebsen, F., and Moros, M.: A decadal-scale Holocene sea surface temperature record from the subpolar North Atlantic constructed using diatoms and statistics and its relation to other climate parameters, Paleoceanography, 23, PA2210, https://doi.org/10.1029/2006PA001339, 2008.

Bini, M., Zanchetta, G., Persoiu, A., Cartier, R., Català, A., Cacho, I., Dean, J. R., Di Rita, F., Drysdale, R. N., Finné, M., Isola, I., Jalali, B., Lirer, F., Magri, D., Masi, A., Marks, L., Mercuri, A. M., Peyron, O., Sadori, L., Sicre, M.-A., Welc, F., Zielhofer, C., and Brisset, E.: The $4.2 \mathrm{ka} \mathrm{BP}$ Event in the Mediterranean region: an overview, Clim. Past, 15, 555-577, https://doi.org/10.5194/cp-15-555-2019, 2019.

Björck, S. and Clemmensen, L. B.: Aeolian sediment in raised bog deposits, Halland, SW Sweden: a new proxy record of Holocene winter storminess variation in southern Scandinavia?, Holocene, 14, 677-688, 2004.

Bojariu, R. and Gimeno, L.: The role of snow cover fluctuations in multiannual NAO persistence, Geophys. Res. Lett., 30, 1156, https://doi.org/10.1029/2002GL015651, 2003.

Booth, R. K., Jackson, S. T., Forman, S. L., Kutzbach, J. E., Bettis III, E. A., Kreigs, J., and Wright, D. K.: A severe centennialscale drought in midcontinental North America 4200 years ago and apparent global linkages, Holocene, 15, 321-328, 2005.

Cartier, R., Sylvestre, F., Paillès, C., Sonzogni, C., Couapel, M., Alexandre, A., Mazur, J.-C., Brisset, E., Miramont, C., and Guiter, F.: Diatom-oxygen isotope record from high-altitude 
Lake Petit (2200 ma.s.1.) in the Mediterranean Alps: shedding light on a climatic pulse at $4.2 \mathrm{ka}$, Clim. Past, 15, 253-263, https://doi.org/10.5194/cp-15-253-2019, 2019.

Cheang, B.-K.: Short- and long-range monsoon prediction in Southeast Asia, in: Monsoons, edited by: Fein, J. S. and Stephens, P. L., John Wiley, New York, 579-606, 1987.

Cheng, H., Sinha, A., Verheyden, S., Nader, F. H., Li, X. L., Zhang, P. Z., Yin, J. J., Yi, L., Peng, Y. B., Rao, Z. G., Ning, Y. F., and Edwards, R. L.: The climate variability in northern Levant over the past 20,000 years, Geophys. Res. Lett., 42, 8641-8650, https://doi.org/10.1002/2015g1065397, 2015.

Clemmensen, L. B., Andreasen, F., Heinemeier, J., and Murray, A.: A Holocene coastal aeolian system, Vejers, Denmark: landscape evolution and sequence stratigraphy, Terra Nova, 13, 129-134, 2003.

Cohen, J., Saito, K., and Entekhabi, D.: The role of the Siberian high in northern hemisphere climate variability, Geophys. Res. Lett., 28, 299-302, https://doi.org/10.1029/2000GL011927, 2001.

Cullen, H. M., deMonecal, P. B., Hemming, S., Hemming, G., Brown, F. H., Guilderson, T., and Sirocko, F.: Climate change and the collapse of the Akkadian empire: Evidence from the deep sea, Geology, 28, 379-382, 2000.

Daley, T. J., Barber, K. E., Street-Perrott, F. A., Loader, N. J., Marshall, J. D., Crowley, S. F., and Fisher, E. H.: Holocene climate variability revealed by oxygen isotope analysis of Sphagnum cellulose from Walton Moss, northern England, Quaternary Sci. Rev., 29, 1590-1601, 2010.

Dalfes, H. N., Kukla, G., and Weiss, H. (Eds.): Third millennium BC climate change and Old World collapse, NATO ASI Series, Springer Verlag, Berlin Heidelberg, Germany, 1997.

D’Arrigo, R., Jacoby, G., Wilson, R., and Panagiotopoulos, F.: A reconstructed Siberian High index since A.D. 1599 from Eurasian and North American tree rings, Geophys. Res. Lett., 32, L05705, https://doi.org/10.1029/2004GL022271, 2005.

Dean, J. R., Jones, M. D., Leng, M. J., Metcalfe, S. E., Sloane, H. J., Eastwood, W. J., and Roberts, C. N.: Seasonality of Holocene hydroclimate in the Eastern Mediterranean reconstructed using the oxygen isotope composition of carbonates and diatoms from Lake Nar, central Turkey, Holocene, 28, 267-276, 2018.

Di Rita, F., Lirer, F., Bonomo, S., Cascella, A., Ferraro, L., Florindo, F., Insinga, D. D., Lurcock, P. C., Margaritelli, G., Petrosino, P., Rettori, R., Vallefuoco, M., and Magri, D.: Late Holocene forest dynamics in the Gulf of Gaeta (central Mediterranean) in relation to NAO variability and human impact, Quaternary Sci. Rev., 179, 137-152, 2018.

Ding, Y. and Krishnamurti, T. N.: Heat Budget of the Siberian High and the Winter Monsoon, Mon. Weather Rev., 115, 2428-2449, 1987.

Drăguşin, V., Balan, S., Blamart, D., Forray, F. L., Marin, C., Mirea, I., Nagavciuc, V., Orăşeanu, I., Perşoiu, A., Tîrlă, L., Tudorache, A., and Vlaicu, M.: Transfer of environmental signals from the surface to the underground at Ascunsa Cave, Romania, Hydrol. Earth Syst. Sci., 21, 5357-5373, https://doi.org/10.5194/hess-215357-2017, 2017.

Drysdale, R., Zanchetta, G., Hellstrom, J., Maas, R., Fallick, A., Pickett, M., Cartwright, I., and Piccini, L.: Late Holocene drought responsible for the collapse of Old World civilizations is recorded in an Italian cave flowstone, Geology, 34, 101-104, https://doi.org/10.1130/G22103.1, 2006.
Eden, C. and Jung, T.: North Atlantic interdecadal variability: oceanic response to the north Atlantic oscillation (1865-1997), J. Climate, 14, 676-691, 2001.

Ersek, V., Onac, B. P., and Perşoiu, A.: Kinetic processes and stable isotopes in cave dripwaters as indicators of winter severity, Hydrol. Process., 32, 2856-2862, 2018.

Finné, M., Holmgren, K., Shen, C.-C., Hu, H.-M., Boyd, M., and Stocker, S.: Late Bronze Age climate change and the destruction of the Mycenaean Palace of Nestor at Pylos, PLOS ONE, 12, e0189447, https://doi.org/10.1371/journal.pone.0189447, 2017.

Fisher, D., Osterberg, E., Dyke, A., Dahl-Jensen, D., Demuth, M., Zdanowicz, C., Bourgeois, J., Koerner, R. M., Mayewski, P., Wake, C., Kreutz, K., Steig, E., Zheng, J., Yalcin, K., GotoAzuma, K., Luckman, B., and Rupper, S.: The Mt Logan Holocene - late Wisconsinan isotope record: tropical PacificYukon connections, Holocene, 18, 667-677, 2008.

Fohlmeister, J., Vollweiler, N., Spötl, C., and Mangini, A.: COMNISPA II: Update of a mid-European isotope climate record, 11 ka to present, Holocene, 23, 749-754, 2013.

Foster, J., Owe, M., and Rango, A.: Snow cover and temperature relationships in North America and Eurasia, J. Appl. Meteorol. Clim., 22, 460-469, 1983.

Gasse, F. and Van Campo, E.: Abrupt post-glacial climate events in West Asia and North Africa monsoon domains, Earth Planet. Sc. Lett., 126, 435-456, 1994.

Geirsdóttir, Á., Miller, G. H., Andrews, J. T., Harning, D. J., Anderson, L. S., Florian, C., Larsen, D. J., and Thordarson, T.: The onset of neoglaciation in Iceland and the $4.2 \mathrm{ka}$ event, Clim. Past, 15, 25-40, https://doi.org/10.5194/cp-15-25-2019, 2019.

Giosan, L., Orsi, W. D., Coolen, M., Wuchter, C., Dunlea, A. G., Thirumalai, K., Munoz, S. E., Clift, P. D., Donnelly, J. P., Galy, V., and Fuller, D. Q.: Neoglacial climate anomalies and the Harappan metamorphosis, Clim. Past, 14, 1669-1686, https://doi.org/10.5194/cp-14-1669-2018, 2018.

Gong, D.-Y. and Ho, C.-H.: The Siberian High and climate change over middle to high latitude Asia, Theor. Appl. Climatol., 72, 19, 2002.

Goslin, J., Fruergaard, M., Sander, L., Gałka, M., Menviel, L., Monkenbusch, J., Thibault, N., and Clemmensen, L. B.: Holocene centennial to millennial shifts in NorthAtlantic storminess and ocean dynamics, Sci. Rep., 8, 12778, https://doi.org/10.1038/s41598-018-29949-8, 2018.

Häkkinen, S. and Rhines, P. B.: Decline of subpolar north Atlantic circulation during the 1990s, Science, 304, 555-559, 2004.

Hao, T., Liu, X., Ogg, J., Liang, Z., Xiang, R., Zhang, X., Zhang, D., Zhang, C., Liu, Q., and Li, X.: Intensified episodes of East Asian Winter Monsoon during the middle through late Holocene driven by North Atlantic cooling events: High-resolution lignin records from the South Yellow Sea, China, Earth Planet. Sc. Lett., 479, 144-155, 2017.

Harris, I., Jones, P. D., Osborn, T. J., and Lister, D. H.: Updated high-resolution grids of monthly climatic observations - the CRU TS3.10 Dataset, Int. J. Climatol., 34, 623-642, 2014.

Hughes, P. D. M., Mauquoy, D., Barber, K. E., and Langdon, P. G.: Mire-development pathways and palaeoclimatic records from a full Holocene peat archive at Walton Moss, Cumbria, England, Holocene, 10, 465-479, 2000.

Hurrell, J. W., Kushnir, Y., Ottersen, G., and Visbeck, M.: An Overview of the North Atlantic Oscillation, in: The North At- 
lantic Oscillation: Climatic Significance and Environmental Impact, American Geophysical Union, Washington D.C., 1-35, 2013.

Ionita, M., Bădăluţă, C.-A., Scholz, P., and Chelcea, S.: Vanishing river ice cover in the lower part of the Danube basin - signs of a changing climate, Sci. Rep., 8, 7948, https://doi.org/10.1038/s41598-018-26357-w, 2018.

Isola, I., Zanchetta, G., Drysdale, R. N., Regattieri, E., Bini, M., Bajo, P., Hellstrom, J. C., Baneschi, I., Lionello, P., Woodhead, J., and Greig, A.: The $4.2 \mathrm{ka}$ event in the central Mediterranean: new data from a Corchia speleothem (Apuan Alps, central Italy), Clim. Past, 15, 135-151, https://doi.org/10.5194/cp15-135-2019, 2019.

Janbu, A. D., Paasche, Ø., and Talbot, M. R.: Paleoclimate changes inferred from stable isotopes and magnetic properties of organicrich lake sediments in Arctic Norway, J. Paleolimnol., 46, 29, https://doi.org/10.1007/s10933-011-9512-2, 2011.

Jhun, J. G. and Lee, E. J.: A new East Asian winter monsoon index and associated characteristics of the winter monsoon, J. Climate, 17, 711-726, 2004.

Kang, S., Wang, X., Roberts, H. M., Duller, G. A. T., Cheng, P., Lu, Y., and An, Z.: Late Holocene anti-phase change in the East Asian summer and winter monsoons, Quaternary Sci. Rev., 188, 28-36, 2018.

Kathayat, G., Cheng, H., Sinha, A., Berkelhammer, M., Zhang, H., Duan, P., Li, H., Li, X., Ning, Y., and Edwards, R. L.: Evaluating the timing and structure of the $4.2 \mathrm{ka}$ event in the Indian summer monsoon domain from an annually resolved speleothem record from Northeast India, Clim. Past, 14, 18691879, https://doi.org/10.5194/cp-14-1869-2018, 2018.

Kobashi, T., Menviel, L., Jeltsch-Thömmes, A., Vinther, B. M., Box, J. E., Muscheler, R., Nakaegawa, T., Pfister, P. L., Döring, M., Leuenberger, M., Wanner, H., and Ohmura, A.: Volcanic influence on centennial to millennial Holocene Greenland temperature change, Sci. Rep., 7, 1441, https://doi.org/10.1038/s41598017-01451-7, 2017.

Larsen, D. J., Miller, G. H., Geirsdóttir, Á., and Ólafsdóttir, S.: Non-linear Holocene climate evolution in the North Atlantic: a high-resolution, multi-proxy record of glacier activity and environmental change from Hvítárvatn, central Iceland, Quaternary Sci. Rev., 39, 14-25, 2012.

Lionello, P., Malanotte-Rizzoli, P., and Boscolo, R.: The Mediterranean Climate: An Overview of the Main Characteristics and Issues, Elsevier, the Netherlands, 2006.

Mayewski, P. A., Meeker, L. D., Whitlow, S., Twickler, M. S., Morrison, M. C., Bloomeld, P., Bond, G. C., Alley, R. B., Gow, A. J., Grootes, P. M., Meese, D. A., Ram, M., Taylor, K. C., and Wumkes, W.: Changes in atmospheric circulation and ocean ice cover over the North Atlantic during the last 41,000 years, Science, 263, 1747-1751, 1994.

Mayewski, P. A., Meeker, L. D., Twickler, M. S., Whitlow, S. I., Yang, Q., Lyons, W. B., and Prentice, M.: Major features and forcing of high-latitude northern hemisphere atmospheric circulation using a 110,000-year-long glaciochemical series, J. Geophys. Res., 102, 26345-26366, 1997.

Mayewski, P. A., Rohling, E. J., Stager, J. C., Karlén, W., Maasch, K. A., Meeker, L. D., Meyerson, E. A., Gasse, F., Van Kreveld, S., Holmgren, K., Lee-Thorp, K., Rosqvist, G., Rack, F., Staub- wasser, M., Schneider, R. R., and Steig, E. J.: Holocene Climate Variability, Quaternary Res., 62, 243-255, 2004.

Meeker, L. D. and Mayewski, P. A.: A 1400-year high-resolution record of atmospheric circulation over the North Atlantic and Asia, Holocene, 12, 257-266, 2002.

Mischke, S. and Zhang, C.: Holocene cold events on the Tibetan Plateau, Global Planet. Change, 72, 155-163, 2010.

Moros, M., De Deckker, P., Jansen, E., Perner, K., and Telford, R. J.: Holocene climate variability in the Southern Ocean recorded in a deep-sea sediment core off South Australia, Quaternary Sci. Rev., 28, 1932-1940, 2009.

Morrill, C., Overpeck, J. T., and Cole, J. E.: A synthesis of abrupt changes in the Asian summer monsoon since the last deglaciation, Holocene, 13, 465-476, 2003.

Muschitiello, F., Schwark, L., Wohlfarth, B., Sturm, C., and Hammarlund, D.: New evidence of Holocene atmospheric circulation dynamics based on lake sediments from southern Sweden: a link to the Siberian High, Quaternary Sci. Rev., 77, 113-124, 2013.

Nesje, A., Matthews, J. A., Dahl, S. O., Berrisford, M. S., and Andersson, C.: Holocene glacier fluctuations of Flatebreen and winter-precipitation changes in the Jostedalsbreen region, western Norway, based on glaciolacustrine sediment records, Holocene, 11, 267-280, 2001.

O’Brien, S. R., Mayewski, P. A., Meeker, L. D., Meese, D. A., Twickler, M. S., and Whitlow, S. I.: Complexity of Holocene climate as reconstructed from a Greenland ice core, Science, 270, 1962-1964, 1995.

Olsen, J., Anderson, N. J., and Knudsen, M. F.: Variability of the North Atlantic Oscillation over the past 5,200 years, Nat. Geosci., 5, 808-812, 2012.

Orme, L. C., Charman, D. J., Reinhardt, L., Jones, R. T., Mitchell, F. J. G., Stefanini, B. S., Barkwith, A., Ellis, M. A., and Grosvenor, M.: Past changes in the North Atlantic storm track driven by insolation and sea-ice forcing, Geology, 45, 335-338, 2017.

Orme, L. C., Miettinen, A., Divine, D., Husum, K., Pearce, C., Van Nieuwenhove, N., Born, A., Mohan, R., and Seidenkrantz, M.-S.: Subpolar North Atlantic sea surface temperature since $6 \mathrm{ka} \mathrm{BP}$ : Indications of anomalous ocean-atmosphere interactions at 42 ka BP, Quaternary Sci. Rev., 194, 128-142, 2018.

Panagiotopoulos, F., Shahgedanova, M., Hannachi, A., and Stephenson, D. B.: Observed Trends and Teleconnections of the Siberian High: A Recently Declining Center of Action, J. Climate, 18, 1411-1422, 2005.

Panait, A., Diaconu, A., Galka, M., Grindean, R., Hutchinson, S. M., Hickler, T., Lamentowicz, M., Mulch, A., Tanţău, I., Werner, C., and Feurdean, A.: Hydrological conditions and carbon accumulation rates reconstructed from a mountain raised bog in the Carpathians: A multi-proxy approach, Catena, 152, 57-68, 2017.

Parker, A. G., Goudie, A. S., Stokes S., and Kennett, D.: A record of Holocene climate change from lake geochemical analyses in southeastern Arabia, Quaternary Res., 66, 465-476, 2006.

Peck, V. L., Allen, C. S., Kender, S., McClymont, E. L., and Hodgson, D. A.: Oceanographic variability on the West Antarctic Peninsula during the Holocene and the influence of upper circumpolar deep water, Quaternary Sci. Rev., 119, 54-65, 2015.

Perşoiu, A., Onac, B. P., and Perşoiu, I.: The interplay between air temperature and ice dynamics in Scărişoara Ice Cave, Romania, Acta Carsologica, 40, 445-456, 2011. 
Perşoiu, A., Onac, B. P., Wynn, J. G., Blaauw, M., Ionita, M., and Hansson, M.: Holocene winter climate variability in Central and Eastern Europe, Sci. Rep., 7, 1196, https://doi.org/10.1038/s41598-017-01397-w, 2017.

Poli, P., Hersbach, H., Dee, D. P., Berrisford, P., Simmons, A. J., Vitart, F., Laloyaux, P., Tan, D. G. H., Peubey, C., Thépaut, J.N., Trémolet, Y., Hólm, E. V., Bonavita, M., Isaksen, L., and Fisher, M.: ERA-20C: An Atmospheric Reanalysis of the Twentieth Century, J. Climate, 29, 4083-4097, 2016.

Regattieri, E., Zanchetta, G., Drysdale, R. N., Isola, I., Hellstrom, J. C., and Dallai, L.: Lateglacial to Holocene trace element record (Ba, Mg, Sr) from Corchia Cave (Apuan Alps, central Italy): palaeoenvironmental implications, J. Quaternary Sci., 29, 381392, 2014.

Renssen, H., Goosse, H., Fichefet, T., Brovkin, V., Driesschaert, E., and Wolk, F.: Simulating the Holocene climate evolution at northern high latitudes using a coupled atmosphere-sea iceocean-vegetation model, Clim. Dynam., 24, 23-43, 2005.

Rîmbu, N., Lohmann, G., Kim, J. H., Arz, H. W., and Schneider, R.: Arctic/North Atlantic Oscillation signature in Holocene sea surface temperature trends as obtained from alkenone data, Geophys. Res. Lett., 30, 1280, https://doi.org/10.1029/2002GL016570, 2003.

Rîmbu, N., Lohmann, G., and Ionita, M.: Interannual to multidecadal Euro-Atlantic blocking variability during winter and its relationship with extreme low temperatures in Europe, J. Geophys. Res., 119, 13621-13636, 2014.

Ruan, J., Kherbouche, F., Genty, D., Blamart, D., Cheng, H., Dewilde, F., Hachi, S., Edwards, R. L., Régnier, E., and Michelot, J.-L.: Evidence of a prolonged drought ca. $4200 \mathrm{yr}$ BP correlated with prehistoric settlement abandonment from the Gueldaman GLD1 Cave, Northern Algeria, Clim. Past, 12, 1-14, https://doi.org/10.5194/cp-12-1-2016, 2016.

Seierstad, I. K., Abbott, P. M., Bigler, M., Blunier, T., Bourne, A. J., Brook, E., Buchardt, S. L., Buizert, C., Clausen, H. B., Cook, E., Dahl-Jensen, D., Davies, S. M., Guillevic, M., Johnsen, S. J., Pedersen, D. S., Popp, T. J., Rasmussen, S. O., Severinghaus, J. P., Svensson, A., and Vinther, B. M.: Consistently dated records from the Greenland GRIP, GISP2 and NGRIP ice cores for the past $104 \mathrm{ka}$ reveal regional millennial-scale $\delta^{18} \mathrm{O}$ gradients with possible Heinrich event imprint, Quaternary Sci. Rev., 106, 29 46, 2014.

Sejrup, H. P., Seppä, H., McKay, N. P., Kaufman, D. S., Geirsdóttir, Á., de Vernal, A., Renssen, H., Husum, K., Jennings, A., and Andrews, J. T.: North Atlantic-Fennoscandian Holocene climate trends and mechanisms, Quaternary Sci. Rev., 147, 365378, 2016.

Shulmeister, J. and Lees, B. G.: Pollen evidence from tropical Australia for the onset of an ENSO-dominated climate at c. $4000 \mathrm{BP}$, Holocene, 5, 10-18, 1995.

Sharifi, A., Pourmand, A., Canuel, E. A., Ferer-Tyler, E., Peterson, L. C., Aichner, B., Feakins, S. J., Daryaee, T., Djamali, M., Beni, A. N., Lahijani, H. A. K., and Swart, P. K.: Abrupt climate variability since the last deglaciation based on a high-resolution, multi-proxy peat record from NW Iran: The hand that rocked the Cradle of Civilization?, Quaternary Sci. Rev., 123, 215-230, 2015.

Smith, A. C., Wynn, P. M., Barker, P. A., Leng, M. J., Noble, S. R., and Tych, W.: North Atlantic forcing of moisture deliv- ery to Europe throughout the Holocene, Sci. Rep., 6, 24745, https://doi.org/10.1038/srep24745, 2016.

Stansell, N. D., Klein, E. S., Finkenbinder, M. S., Fortney, C. S., Dodd, J. P., Terasmaa, J., and Nelson, D. B.: A stable isotope record of Holocene precipitation dynamics in the Baltic region from Lake Nuudsaku, Estonia, Quaternary Sci. Rev., 175, 73-84, 2017.

Staubwasser, M. and Weiss, H.: Holocene climate and cultural evolution in late prehistoric-early historic West Asia, Quaternary Res., 66, 372-387, 2006.

Staubwasser, M., Sirocko, F., Grootes, P., and Segl, M.: Climate change at the $4.2 \mathrm{kaBP}$ termination of the Indus valley civilization and Holocene south Asian monsoon variability. Geophys. Res. Lett., 30, 1425, https://doi.org/10.1029/2002GL016822, 2003.

Steinhilber, F., Beer, J., and Fröhlich, C.: Total solar irradiance during the Holocene, Geophys. Res. Lett., 36, L19704, https://doi.org/10.1029/2009GL040142, 2009.

Thornalley, D. J. R., Elderfield, H., and McCave, I. N.: Holocene oscillations in temperature and salinity of the surface subpolar North Atlantic, Nature, 457, 711-714, 2009.

Ulbrich, U., Lionello, P., Belušić, D., Jacobeit, J., Knippertz, P., Kuglitsch, F. G., Leckebusch, G. C., Luterbacher, J., Maugeri, M., Maheras, P., Nissen, K. M., Pavan, V., Pinto, J. G., Saaroni, H., Seubert, S., Toreti, A., Xoplaki, E., and Ziv, B.: 5 - Climate of the Mediterranean: Synoptic Patterns, Temperature, Precipitation, Winds, and Their Extremes, in: The Climate of the Mediterranean Region, Elsevier, Oxford, 301-346, 2012.

Vossel, H., Roeser, P., Litt, T., and Reed, J. M.: Lake Kinneret (Israel): New insights into Holocene regional palaeoclimate variability based on high-resolution multi-proxy analysis, Holocene, 28, 1395-1410, 2018.

Walczak, I. W., Baldini, J. U. L., Baldini, L. M., McDermott, F., Marsden, S., Standish, C. D., Richards, D. A., Andreo, B., and Slater, J.: Reconstructing high-resolution climate using CT scanning of unsectioned stalagmites: A case study identifying the mid-Holocene onset of the Mediterranean climate in southern Iberia, Quaternary Sci. Rev., 127, 117-128, 2015.

Walker, M., Head, M. J., Berkelhammer, M., Björck, S., Cheng, H., Cwyna, L., Fisher, D., Gkinis, V., Long, A., Lowe, J., Newnham, R., Rasmussen, S. O., and Weiss, H.: Formal ratification of the subdivision of the Holocene Series/Epoch (Quaternary System/Period): two new Global Boundary Stratotype Sections and Points (GSSPs) and three new stages/subseries, Episodes, 41, 213-223, 2018.

Walker, M. J. C., Berkelhammer, M., Björck, S., Cwynar, L. C., Fisher, D. A., Long, A. J., Lowe, J. J., Newnham, R. M., Rasmussen, S. O., and Weiss, H.: Formal subdivision of the Holocene Series/Epoch: a Discussion Paper by a Working Group of INTIMATE (Integration of ice-core, marine and terrestrial records) and the Subcommission on Quaternary Stratigraphy (International Commission on Stratigraphy), J. Quaternary Sci., 27, 649-659, 2012.

Wang, Y., Cheng, H., Edwards, R. L., He, Y., Kong, X., An, Z., Wu, J., Kelly, M. J., Dykoski, C. A., and Li, X.: The Holocene Asian monsoon: links to solar changes and North Atlantic climate, Science, 308, 854-857, 2005. 
Wanner, H., Solomina, O., Grosjean, M., Ritz, S. P., and Jetel, M.: Structure and origin of Holocene cold events, Quaternary Sci. Rev., 30, 3109-3123, 2011.

Wassenburg, J. A., Dietrich, S., Fietzke, J., Fohlmeister, J., Jochum, K. P., Scholz, D., Richter, D. K., Sabaoui, A., Spotl, C., Lohmann, G., Andreae, M. O., and Immenhauser, A.: Reorganization of the North Atlantic Oscillation during early Holocene deglaciation, Nat. Geosci., 9, 602-605, 2016.

Weiss, H.: Global megadrought, societal collapse and resilience at 4.2-3.9 ka BP across the Mediterranean and west Asia, PAGES, 24, 62-63, 2016.

Weiss, H., Courty, M.-A., Wetterstrom, W., Guichard, F., Senior, L., Meadow, R., and Curnow, A.: The Genesis and Collapse of Third Millennium North Mesopotamian Civilization, Science, 261, 995-1004, 1993.

Wolff, C., Plessen, B., Dudashvilli, A. S., Breitenbach, S. F., Cheng, H., Edwards, L. R., and Strecker, M. R.: Precipitation evolution of Central Asia during the last 5000 years, Holocene, 27, 142$154,2017$.
Wu, B. and Wang, J.: Winter Arctic Oscillation, Siberian High and East Asian Winter Monsoon, Geophys. Res. Lett., 29, 3-1-3-4, https://doi.org/10.1029/2002GL015373, 2002.

Yang, H., Wang, K., Dai, H., Wang, Y., and Li, Q.: Wind effect on the Atlantic meridional overturning circulation via sea ice and vertical diffusion, Clim. Dynam., 46, 3387-3403, 2016.

Zanchetta, G., Van Welden, A., Baneschi, I., Drysdale, R., Sadori, L., Roberts, N., Giardini, M., Beck, C., Pascucci, V., and Sulpizio, R.: Multiproxy record for the last 4500 years from Lake Shkodra (Albania/Montenegro), J. Quaternary Sci., 27, 780-789, 2012.

Zielhofer, C., Fletcher, W. J., Mischke, S., De Batist, M., Campbell, J. F. E., Joannin, S., Tjallingii, R., El Hamouti, N., Junginger, A., Stele, A., Bussmann, J., Schneider, B., Lauer, T., Spitzer, K., Strupler, M., Brachert, T., and Mikdad, A.: Atlantic forcing of Western Mediterranean winter rain minima during the last 12,000 years, Quaternary Sci. Rev., 157, 29-51, 2017. 